\title{
PELAKSANAAN PENILAIAN AUTENTIK PADA PEMBELAJARAN PPKN PADA SEKOLAH MENENGAH ATAS DI KOTA SEMARANG
}

\author{
Margi Wahono \\ Program Studi Pendidikan Pancasila dan Kewarganegaraan Universitas Negeri \\ Semarang \\ margi85@mail.unnes.ac.id
}

\begin{abstract}
ABSTRAK
Penilaian yang dilaksanakan oleh guru digunakan untuk memantau proses, kemajuan belajar dan perbaikan hasil belajar peserta didik secara berkelanjutan yang digunakan untuk menilai pencapaian kompetensi peserta didik. Penelitian ini bertujuan untuk mendeskripsikan pemahaman guru tentang penerapan penilaian kurikulum 2013, mendeskripsikan permasalahan guru dalam penerapan penilaian kurikulum 2013, kendala-kendala guru serta upaya yang dilakukan guru dalam mengatasi permasalahan penerapan penilaian kurikulum 2013 pada Sekolah Menengah Atas di Kota semarang. Jenis peneltian ini adalah penelitian kualitatif. Teknik pengumpulan data yang digunakan adalah observasi, wawancara dan dokumentasi. Teknik pemeriksaan keabsahan data dilakukan dengan triangulasi teknik dan sumber. Penelitian menunjukkan pada jenjang Sekolah Menengah Atas Di Semarang dalam pembelajaran PPKn telah melaksanakan penilaian autentik. Penilaian autentik ini diharapkan mampu meningkatkan kemampuan afektif siswa sehingga siswa tidak hanya unggul dalam bidang kognitif saja. Namun, dalam pelaksanaanya penilaian autentik mengalami beberapa hambatan seperti karakter siswa dalam setiap kelas berbedabeda, alokasi waktu yang terbatas, dan temuan dilapangan adalah guru merasa kurang memahami pelaksanaan penilaian autentik karena minimnya sosialisasi dan pelatihan mengenai penilaian autentik. Penulis memberikan rekomendasi khususnya pada guru agar lebih mengoptimalkan penerapan penilaian autentik dalam penilaian pembelajaran PPKn.

Kata kunci: Penilaian Autentik, Pembelajaran PPKn, Sekolah Menengah Atas
\end{abstract}

\section{ABSTRACT}

Assessments carried out by teachers are used to monitor the process, progress of learning and improve student learning outcomes on an ongoing basis which is used to assess the achievement of student competencies. This study aims to describe the teacher's understanding of the application of the 2013 curriculum assessment, describe the teacher's problems in applying the 2013 curriculum assessment, teacher constraints and the efforts made by teachers in overcoming the problems of applying the 2013 curriculum assessment 
Jurnal Pendidikan Pancasila dan Kewarganegaraan

Volume I Nomor I (Juni) 2020

in High Schools in Semarang City. This type of research is qualitative research. Data collection techniques used were observation, interviews and documentation. The technique of checking the validity of the data is carried out by triangulation of techniques and sources. Research shows at the level of high school in Semarang in learning PPKn has carried out authentic assessment. This authentic assessment is expected to be able to improve students' affective abilities so that students are not only superior in the cognitive field. However, in the implementation of authentic assessment there are several obstacles such as the character of students in each class is different, limited time allocation, and findings in the field is the teacher feels less understanding of the implementation of authentic assessment because of the lack of socialization and training on authentic assessment. The author provides recommendations specifically for teachers to further optimize the application of authentic assessment in the assessment of PPKn learning.

Keywords: Authentic Assessment, Ppkn Learning, Senior High School

\section{PENDAHULUAN}

Salah satu yang menjadi penekanan dalam kurikulum 2013 adalah penilaian autentik. Kunandar (2013) menyatakan bahwa dengan melalui kurikulum 2013 ini, penilaian autentik menjadi penekanan yang serius dimana guru dalam melakukan penilaian hasil belajar peserta didik harus benar-benar memperhatikan penilaian autentik. Penilaian otentik merupakan penilaian yang dilakukan secara komprehensif untuk menilai mulai dari masukan (input), proses, dan keluaran (output) pembelajaran (Departemen Pendidikan dan Kebudayaan, 2006; Lunawati, 2018; Maghfiroh, 2015). Dengan adanya penilaian autentik, dapat diketahui seberapa besar keberhasilan peserta didik menguasai kompetensi atau materi yang telah diajarkan secara nyata sesuai kemampuannya. Penilaian autentik mampu menggambarkan peningkatan hasil belajar peserta didik baik dalam rangka mengobservasi, menalar, mencoba, dan membangun jejaring. Selain itu dapat memberikan kesempatan yang luas kepada peserta didik untuk dapat menerapkan pengetahuan, keterampilan, dan sikap yang dimilikinya. Penilaian ini dapat digunakan untuk menggambarkan kondisi siswa yang sebenarnya sesuai dengan kajian-kajian kepustakaan yang ada.

Penilaian autentik sebagaimana tuntutan Kurikulum 2013 tidak mudah diterapkan oleh guru, salah satu penyebabnya adalah guru belum terbiasa dan belum terlatih untuk melakukan penilaian dengan pendekatan autentik, aspek sikap maupun keterampilan jarang dinilai. Padahal Kurikulum 2013 menekankan ketiga aspek tersebut secara seimbang. Karena itu pelaksanaan penilaian autentik pada kurikulum 2013 kurang 
Jurnal Pendidikan Pancasila dan Kewarganegaraan

Volume I Nomor I (Juni) 2020

optimal. Fakta ini diperkuat bahwa Hal ini juga diperkuat dengan penelitian yang dilakukan oleh Utari (2014), hasilnya menunjukkan bahwa pelaksanaan penilaian autentik pada aspek afektif baru sebesar 52,8\%, sedang aspek psikomotorik sebesar 48,4\%, dan pada aspek kognitif dominan, yaitu sebesar 98,8\%, dengan demikian dapat disimpulkan bahwa pelaksanaan penilaian autentk masih kurang optimal (Utari, 2014).

Dengan adanya kurikulum 2013 guru juga menilai sikap dan keterampilan peserta didik. Guru harus mencermati karakter masingmasing peserta didik saat proses pembelajaran berlangsung. Permasalahan di atas, dapat diketahui belum optimalnya penilaian autentik pada Kurikulum 2013, maka penulis tertarik untuk melakukan penelitian yang berjudul "Pelaksanaan Penilaian Autentik Pada Pembelajaran PPKn Pada Sekolah Menengah Atas di Kota Semarang".

\section{METODE PENELITIAN}

Jenis penelitian yang digunakan dalam penelitian ini jenis penelitian deskriftif. Penelitian dengan menggunakan metode deskriftif memberikan gambaran, merinci, dan menganalisa data pada permaslahan yang terjadi saat ini serta memusatkan pada pemecahan permasalahan yang aktual. Adapun dalam penelitian ini menggunakan pendekatan kualitatif. Berkaitan dengan hal ini Trianto (2007) menjelaskan bahwa pendekatan kualitatif adalah penelitian yang mengungkapkan, menganalisis, lalu menginterpertasikannya dari objek yang ada pada keadaan tertentu. Lokasi penelitian ini yaitu SMA teuku umar dan bebearpa sejolah menengah atas di kota semarang, waktu penelitian berlangsung pada bulan juli sampai dengan agustus 2019. Sumber data dalam penelitian ini ilah guru mata pelajaran PPKn dan ppeserta didik, serat berbagai literatur yang berkaitan dengan penilaian autentik serat Rencana Pelaksanaan Pembelajaran (RPP) mata pelajaran yang dusuusn oleh guru

Adapun teknik pengumpulan data yang dilakukan dalam melakukan penelitian ini adalah sebagai berikut: Angket, yaitu suatu metode yang digunakan dalam penelitian ini untuk memberikan selebaran kertas yang didalamnya terdapat daftar pertanyaan kepada orang yang bersangkutan dengan maksud agar orang yang diberi tersebut bersedia memberikan respons sesuai dengan permintaan pengguna. Teknik analisis data dan uji keabsahan data menggunakan reduksi data dan triangulasi.

Wawancara, yaitu suatu pedoman yang digunakan untuk melakukan tanya jawab agar pertanyaan tersebut lebih terarah dengan baik. Pertanyaan tersebut diajukan kepada pihak-pihak yang terkait untuk 
Jurnal Pendidikan Pancasila dan Kewarganegaraan

Volume I Nomor I (Juni) 2020

memperoleh dan mengumpulkan data informasi mengenai asalah yang diteliti, dalam hal ini Guru PPKn tingkat Sekolah Menengah Atas di Kota Semarang.

Observasi, digunakan dalam penelitian ini dengan tujuan untuk memperoleh suatu gambaran yang jelas melalui pengamatan yang dilakukan secara langsung terhadap objek penelitian. Dengan observasi dapat mengumpulkan data secara lebih cermat dan terinci. Dokumentasi, digunakan dalam penelitian ini karena setiap kegiatan dan tindakan yang dilakukan memerlukan bukti yang akurat dan bukti nyata yang dapt dilihat oleh orang lain. Dengan dokumentasi ini dapat mengumpulkan informasi dengan bukti nyata yang dapat dilihat langsung bentuknya.

\section{HASIL DAN PEMBAHASAN}

\section{Implementasi Penilaian Autentik Pada Sekolah Menengah Atas di Kota Semarang}

Patokan penilaian autentik mata pelajaran PPKn aitu sesuai dengan RPP yang telah disusun sesuai dengan kreatifitasan guru dengan mempertimbangkan keadaan siswa. Dalam pengambilan nilai mata pelajaran PPKn lebih difokuskan pada nilia sikap (afektif) karena PPKn adalah mata pelajaran untuk menanamkan nilai karakter yang baik.

Penilaian tertulis digunakan guru untuk meberikan penilain kepada siswa terhadap kemampuan kognitif siswa, dalam mengingat, memahami, mengorganisasikan, menerapkan, menganalisis, mensitesis, mengevaluasi, dan sebagainya atas materi yang sudah dipelajari. Tes tertulis ini diberikan saat di akhir pembelajaran setiap bab dan diakhir semester. Tes berbentuk esai dengan jenis jawaban yang terbuka (extended-response). Selain menggunakan tes tertuli, pak edris juga menilai kemampuan kognitif siswa saat siswa melakukan presentasi di depan kelas. Guru melihat materi yang disampaikan, dan saat siswa menjawab pertanyaan-pertanyaan yang muncul dari teman-temannya.

Observasi perilaku siswa oleh guru yang dicatat dalam anekdot record dilakukan untuk memperoleh nilai kemampuan afektif siswa. Penilaian afektif dilakukan setiap waktu, baik saat pembelajaran di kelas maupun di luar kelas, bahkan juga saat di waktu istirahat. Dimana saat istirahat itulah siswa akan menunjukkan kemampuan afektifnya saat berinteraksi dengan lingkungan sekolah. Dan pada saat pembelajaran di dalam kelas penilian efektif diambil dari keaktifan siswa saat menerima atau memperhatikan, merespon, dan mengkomunikasikan. Sedangkan saat pembelajaran di luar kelas guru melihat respon siswa terhadap aktivitas 
Jurnal Pendidikan Pancasila dan Kewarganegaraan

Volume I Nomor I (Juni) 2020

masyarakat diluar sana. Sebagai contoh pembelajaran di luar kelas berkaitan dengan ketertiban masyarakat dalam berlalulintas, hal ini dipilih karena letak sekolah di pinggir jalan besar. Siswa mengamati dan merespon atas keadaan masyarakata saat berlalulintas.

Penilaian melalui observasi dilakukan guru untuk mengukur tingkat pencapaian kompetensi sikap siswa secara berkesinambungan dengan menggunakan indra, baik secara langsung maupun tidak langsung. Teknis pelaksanaannya menggunakan pedoman atau lembar observasi yang berisi sejumlah indikator perilaku atau aspek yang diamati atau juga perilaku yang diharapkan muncul pada dari siswa dalam keadaan tertentu. Observasi juga didasari asumsi bahwa perilaku seseorang pada umumnya menunjukkan kecenderungan dalam tertentu. Lembar observasi menggunakan daftar cek yang memuat indikator perilaku yang diharapkan muncul dari siswa \{Muthali'in: 2017).

Penilain kerja oleh siswa digunakan guru untuk mendapatkan nilai kemampuan psikomotorik siswa. Penilaian ini cocok untuk menilai kemampuan praktek siswa. Pengambilan nilai dilakukan saat siswa secara berkelompok menyiapkan suatu metari kemudian dipresentasikan. Dalam kegiatan tersebut kemampuan siswa dalam menalar, bekerjasama dan mengkomunikasikan akan muncul. Penilaian ini dilakukan dengan menggunakan daftar cek list, dan skala pemilaian.

Pada dasarnya, penilaian autentik yang ada dan dilakukan oleh guru PPKn pada sekolah-sekolah yang menjadi objek penelitian mencakup 3 aspek penilaian secara umum yaitu:

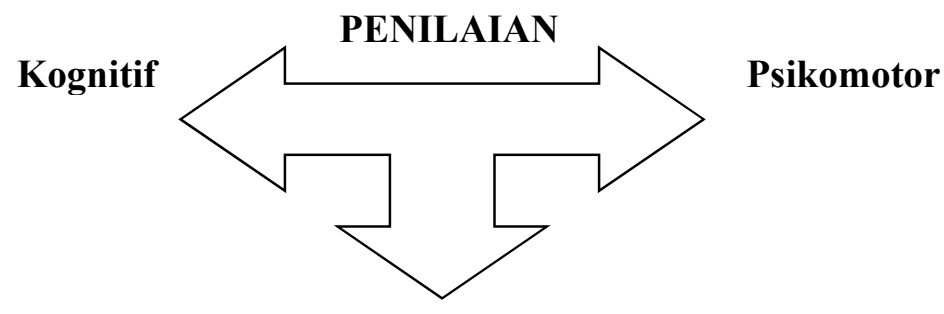

Afektif

Gambar 1. Aspek Penilaian

1. Aspek kognitif (pengetahuan) $\rightarrow$ aspek ini berkaitan dengan kemampuan siswa dalam hal kompetensi dan pengetahuan tentang materi yang disampaikan guru.

2. Aspek afektif (sikap) $\rightarrow$ aspek ini berkaitan dengan sikap peserta didik dalam proses pembelajaran di kelas ataupun tingkah laku peserta didik di luar kelas. 
Jurnal Pendidikan Pancasila dan Kewarganegaraan

Volume I Nomor I (Juni) 2020

3. Aspek psikomotor (keterampilan) $\rightarrow$ aspek ini berkaitan erat dengan cara peserta didik mengungkapkan dan menunjukkan keterampilannya terkait dengan materi yang dibahas dan diajarkan.

Dari hasil penelitian yang dilakukan, 3 (tiga) aspek dalam penilaian autentik memiliki ranah-ranah penilaian masing-masing seperti pada tabel berikut ini:

Tabel 1

Ranah penilain dalam penilaian autentik

\begin{tabular}{cll}
\hline \multicolumn{1}{c}{ Kognitif } & \multicolumn{1}{c}{ Aspek Penilaian } & \multicolumn{1}{c}{ Afektif } \\
\hline $\begin{array}{c}\text { UHT (Ulangan Harian } \\
\text { Terprogram) }\end{array}$ & $\begin{array}{l}\text { Tutur kata dengan guru } \\
\text { dan teman }\end{array}$ & $\begin{array}{l}\text { Keterampilan } \\
\text { bertanya }\end{array}$ \\
\hline $\begin{array}{c}\text { UTS (Ulangan Tengah } \\
\text { Semester) }\end{array}$ & $\begin{array}{l}\text { Perilaku saat kegiatan } \\
\text { pembelajaran }\end{array}$ & $\begin{array}{l}\text { Keterampilan } \\
\text { menjawab } \\
\text { pertanyaan }\end{array}$ \\
\hline $\begin{array}{c}\text { UAS (Ulangan Akhir } \\
\text { Semester) }\end{array}$ & Cara berpakaian & $\begin{array}{l}\text { Keterampilan } \\
\text { berargumentasi }\end{array}$ \\
\hline Kuis tiap pertemuan & $\begin{array}{l}\text { Rapi atau tidaknya keadaan } \\
\text { meja dan kursi }\end{array}$ & \\
\hline Tugas harian & $\begin{array}{l}\text { Kesiapan pengumpulan } \\
\text { tugas }\end{array}$ & \\
\hline
\end{tabular}

Hasil dari penilaian juga dapat membangkitkan minat dan motivasi belajar siswa. Dengan adanya persaingan yang terjadi dikelas maka motivasi belajar siswa akan naik dan tujuan dari sebuah peilaian akan tercapai (sutama, 2017).

\section{Hambatan dalam Pelaksanaan Penilaian Autentik}

Penilaian autentik atau penilaian secara langsung dan menyeluruh menjadi titik tumpu keberhasilan implementasi atau penerapan Kurikulum 2013. Kurikulum 2013 yang diterapkan sejak tahun 2013 dan masih digunakan sampai saat ini dalam penerapannya pasti terdapat kendala-kendala khususnya dalam sistem penilaian hasil belajar yang mengharuskan menekankan penilaian pada tiga aspek yaitu: sikap, pengetahuan dan keterampilan. Dari tiga aspek penilaian tersebut, penilaian sikap menjadi penilaian paling utama sebelum menilai pengetahuan dan keterampilan.

Dalam penerapan kurikulum 2013 sejauh ini di beberapa sekolahsekolah yang menjadi lokasi penelitian terdapat berbagai macam kendala, antara lain: 
Jurnal Pendidikan Pancasila dan Kewarganegaraan

Volume I Nomor I (Juni) 2020

1. Perubahan proses pembelajaran, dari yang semula berfokus pada guru sekarang menjadi berfokus pada siswa. Siswa belum dapat mandiri untuk melakukan proses pembelajran sendiri karena sudah terbiasa menerima langsung dari guru.

2. Penyampaian materi harus dilakukan guru dengan berbagai kreatifitas, seperti bercerita tentang kehidupan sehari-hari yang kemudian dihubungkan dengan materi suatu mata pelajaran.

3. Minimalnya jam pelajaran menjadikan materi harus disampaikan secara cepat bahkan menyita waktu mata pelajaran yang lain

4. Penyampaian materi tidak hanya di kelas disebabkan siswa akan merasa jenuh, ada saatnya siswa menerima pelajaran di luar kelas

Kurikulum 2013 yang menggunakan penilaian autentik juga memiliki kendala tertentu, kendala yang dihadapi dalam penilaian autentik adalah:

1. Kendala pada aspek perencanaan, perencanaan penilaian autentik yang rumit, perencanaan penilaian yang rumit dikarenakan masih kurangnya pemahaman dalam membuat instrumen penilaian yang baik dan benar serta banyaknya komponen penilaian yang terdiri dari 3 aspek yang harus direncanakan sebelum pelaksanaan penilaian autentik.

2. Kendala lain dialami pada aspek pelaksanaan, dalam pelaksanaan penilaian autentik kendala yang dialami yaitu banyak komponen yang harus dikontrol secara bersamaan yaitu aktivitas siswa dalam penguasaan pengetahuan, perkembangan sikap, dan keterampilan yang dapat ditunjukannya dan dalam penilaian sikap guru harus menilai sedetail mungkin perilaku dan sikap siswa secara menyeluruh sedangkan jumlah siswa dalam kelas umumnya masih sangat banyak. Namun di sekolah ini diusahakan setiap guru menilai masing-masing diri siswa dengan semestinya pada setiap aspek dan untuk penilaian sikap lebih diutamakan karena ahlaq merupakan hal terpenting dalam diri siswa dan sesuai dengan tujuan sekolah yaitu untuk membangun generasi muda yang berbudi pekerti baik.

3. Kendala aspek manajemen, kendala yang dialami yaitu rumitnya perhitungan nilai hasil belajar siswa dan perekapan hasil nilai peserta didik. Perhitungan nilai yang harus dilakukan guru perlu menggunakan pedoman penskoran yang benar dan rubrik penilaian, dan tentunya hal tersebut membutuhkan waktu yang lama.

Mueller (2006) menyatakan bahwa "ada beberapa langkah-langkah penilaian autentik yaitu: 1) mengidentifikasi standar, 2) memilih suatu tugas autentik, 3) membuat kriteria tugas, dan 4) menciptakan standar kriteria atau rubrik". Mulyasa, (2012) mengemukakan bahwa penialaian 
Jurnal Pendidikan Pancasila dan Kewarganegaraan

Volume I Nomor I (Juni) 2020

unjuk kerja mengacu pada elemen-elemen kinerja yang dapat diukur melalui; (a) kualitas penyelesaian pekerjaan, (b) ketrampilan menggunakan alat-alat, (c) kemampuan menganalisis dan merencanakan prosedur kerja sampai selesai, (d) ketrampilan mengambil keputusan berdasarkan aplikasi informasi yang diberikan, dan (e) kemampuan membaca, menggunakan diagram, gambar-gambar dan simbol-simbol.

Dalam pelaksanaan kurikulum 2013, semua guru bukan hanya guru mata pelajaran PPKn menggunakan sistem penilaian berdasarkan format kurikulum 2013 yaitu pertama adalah penilaian sikap dengan instrumen penilaian yaitu observasi, penilaian diri (self assessment), penilaian teman sebaya dan penilaian jurnal. Kedua yaitu penilaian pengetahuan denga instrumen penilaian tes dan non tes, observasi terhadap diskusi, tanya jawab dan percakapan serta penugasan. Dan yang ketiga adalah penilaian keterampilan dengan instrumen penilaian yaitu untuk kerja/kinerja/praktik, proyek dan protofolio.

Hakekat penilaian otentik adalah menilai apa yang seharusnya dinilai, yaitu : (a) menilai dengan berbagai cara dan berbagai sumber, (b) mengukur pengetahuan dan ketrampilan siswa, (c) mempersyaratkan penerapan pengetahuan dan pengalaman, (d) tugas-tugas yang kontekstual dan relevan, serta (e) proses dan produk yang keduanya dapat diukur. Sedangkan cirri-ciri penilaian otentik adalah : (a) harus dapat mengukur semua aspek pembelajaran, (b) penilaian dilakukan selama proses hingga hasil pembelajaran, (c) menggunakan berbagai cara/metode dan berbagai sember belajar, (d) menggunakan berbagai alat/instrument penilaian. (e) tugas-tugas yang diberikan kepada siswa setiap hari harus dapat mencerminkan pengalaman yang mereka lakukan dan penilaian harus menekankan pada kedalaman (kualitas) pengetahuan dan keahlian siswa bulan keluasannya (kuantitas) (Dyah Sriwilujeng dan Ari Pujiastuti, 2011:45; Pantiawati, 2013).

\section{KESIMPULAN}

Implementasi Penelitian autentik dilakukan secara komprehensif untuk menilai mulai dari masukan, proses dan keluaran pembelajaran (Armini, Marhaeni, Mertasari, 2019; Sihombing, 2016). Secara konseptual penilaian autentik lebih bermakna secara signifikan dibandingkan dengan tes pilihan ganda berstandart sekalipun. Pada jenjang Sekolah Menengah Atas di kota Semarang khususnya dalam pembelajaran PPKn telah melaksanakan penilaian autentik. Dalam penilaian autentik ini diharapkan mampu meningkatkan kemampuan afektif siswa sehingga siswa tidak 
Jurnal Pendidikan Pancasila dan Kewarganegaraan

Volume I Nomor I (Juni) 2020

hanya unggul dalam bidang kognitif saja. Namun, dalam pelaksanaanya penilaian autentik mengalami beberapa hambatan seperti karakter siswa dalam setiap kelas berbeda-beda, alokasi waktu yang terbatas, dll.

\section{DAFTAR PUSTAKA}

Armini, N. W. Y., Marhaeni, D. A. I. N., \& Mertasari, N. M. S. (2019). Studi Evaluatif Implementasi Asesmen Autentik Pada Mata Pelajaran PPKn Kelas X dengan Model Diskrepansi Di SMA Negeri Se-Kota Denpasar. Jurnal Penelitian dan Evaluasi Pendidikan Indonesia, 7(1), 24-34. Departemen Pendidikan dan Kebudayaan. (2006). Penilaian Otentik Pada Pembelajaran Tematik. Malang: Pusat Pengembangan Penataran Guru IPS dan PMP Malang.

Kunandar. (2013). Penilaian Authentik (Penilaian Hasil Belajar Peserta Didik Berdasarkan Kurikulum 2013). Jakarta: Rajawali pers.

Lunawati, R. (2018). Kinerja Guru PPKn Dalam Pengembangan Penilaian Autentik (Study di SMP Negeri 1 Batulayar Kecamatan Batulayar Lombok Barat). Disertasi. Mataram: Universitas Mataram.

Maghfiroh, U. (2015). Pelaksanaan Penilaian Pembelajaran Mata Pelajaran PPKn Kelas VII SMP Negeri 1 Lasem dan SMP Negeri 1 Sedan Berdasarkan Kurikulum 2013. Disertasi. Semarang: Universitas Negeri Semarang).

Mueller, Jon. (2006). Authentic Asessment. North Central College. Tersedia: http://jonatan.muller.faculty.noctrl.edu/toolbox/whatisist.htm diakses pada Rabu, 14 Agustus 2019.

Mulyasa, E. (2012). Uji Kompetensi dan Penilaian Kinerja Guru. Bandung: Remaja Rosdakarya.

Muthali'in, A., \& Iriani, S. (2017). Penilaian Autentik Mata Pelajaran Pendidikan Pancasila Dan Kewarganegaraan (PPKn) Studi Kasus Pelaksanaan Penilaian dalam Kurikulum 2013 di SMP Negeri 2 Colomadu Kabupaten Karanganyar. Prosiding Seminar Nasional Pendidikan Berkemajuan dan Menggembirakan (The Progressive \& Fun Education Seminar) ke-2.

Pantiawati, Yuni. (2013). Hakekat Assessment Autentik dan Penerapannya dalam Pembelajaran Biologi. JEMS. Vol. 1 No. 1, Maret 2013 -- ISSN : 2337- 9049 .

Sihombing, A. (2016). Kompetensi Guru PPKn Dalam Mengimplementasikan Penilaian Autentik Berdasarkan K-13 di SMK NEGERI 9 MEDAN. Disertasi. Medan: Universitas Negeri Medan. 
Jurnal Pendidikan Pancasila dan Kewarganegaraan

Volume I Nomor I (Juni) 2020

Sutama, S., Sandy, G. A., \& Fuadi, D. (2017). Pengelolaan Penilaian Autentik Kurikulum 2013 Mata Pelajaran Matematika di SMA. Manajemen Pendidikan, 12(1), 105-114.

Trianto. (2007). Model Pembelajaran Terpadu dalam Teori dan Praktek. Jakarta: Prestasi Pustaka

Utari, Diah Tri. (2014). Pelaksanaan Penilaian Autentik (Authentic Assesment) Oleh Guru IPA DI SMP Negeri se Kecamatan Karanganyar. Skripsi. Surakarta: Fakultas Keguruan dan Ilmu Pendidikan. Universitas Muhammadiyah Surakarta.

Wilujeng, D dan Pujiastuti, A. (2011). Silabus dan Sistem Penilaian Pembelajaran Tematik. Malang: Tim Tematik PPPPTK Pkn IPS Batu. 